\title{
CHICKEN-AND-EGG DILEMMA BETWEEN INCOME AND ALMS: REVIEW OF ISLAMIC PERSPECTIVES
}

Fitri Nurjanah', Mutiara Sakinah², Askar Muhammad ${ }^{3}$

1,2 Faculty of Economics and Business, Indonesia University

3 Faculty of Economics and Business, Indonesia University; Institute for

Demographic and Poverty Studies (IDEAS)

Email: fitrinj17@gmail.com (correspondence)

\begin{abstract}
Indonesia is the most generous country in the world. This opinion is evident from the World Giving Index created by the Charities Aid Foundation, which has placed Indonesia in the world's number one position in 2018. There is an increase compared to the previous year, where Indonesia was in second place after Myanmar. The leading indicators are donating money, helping foreigners, and participating in volunteer activities. On the other hand, the World Bank in 2018 placed Indonesia in the sixteenth position based on GDP Current USD and the eighth position based on GDP PPP Current USD. This data proves that income is not the main thing that encourages someone to give alms. However, it is still uncertain whether the income and level of charities correlate with each other. Jones and Posnett (1991) revealed that an increase in giving alms behavior is not in line with an increase in household income. On the other hand, there is a significant positive relationship between income and a person's level of alms (Mohd Arshad, 2016). The two types of research mentioned (Jones and Posnett, 1991; Mohd Arshad, 2016) conducted testing at the micro-level. Therefore, this research will concentrate more on the macro level. Pharoah and Tanner (1997) explain that people who consider religion in their lives tend to give more. This study uses a quantitative approach to test the correlation between the World Giving Index and GDP using the Spearman rank correlation test. The Spearman rank correlation test measures the correlation between two random variables based on ranking order. The author has found that there is no correlation between high income and the desire to give alms. This research can used as a reference for the Indonesian government to reduce inequality and poverty in the country by realizing the potential of alms in Indonesia.
\end{abstract}

Keywords: Correlation, World Giving Index, Alms, Gross Domestic Product 


\section{Introduction}

COVID-19 Pandemic devastated the economy. Indonesia's economic growth, for the first time since 1998, must contract. The latest statistical release shows that the economic growth for 2020 fell $-2,07 \%$. In response to the economic contraction, the Indonesian Government (GoI) has launched the national economic recovery program (Pemulihan Ekonomi Nasional $P E N)$. The distribution of social assistance programs such as direct cash transfer included in that program by Government. Yet, the GoI cannot work alone. National economic recovery is also the responsibility of the people. To recover the economy, the people can participate through charity and helping each other.

Indonesian people are known for their hospitality, generosity, and also a sense of cooperation. This assumption also has empirical evidence, namely the World Giving Index (WGI) initiated by The Charities Aid Foundation (CAF), in 2018 placing Indonesia as the first rank among other countries. The indexing measurement is based on several indicators, including donating money, helping foreigners, and participating in voluntary activities. The indicator that contributed most to the highest score for Indonesians was the level of donating money at $78 \%$, followed by volunteer activities a 53\%, and finally helping foreigners at $46 \%$. If depicted in a graph, Indonesia's WGI score in the period 2014 - 2018 tends to experience an upward trend as follows:

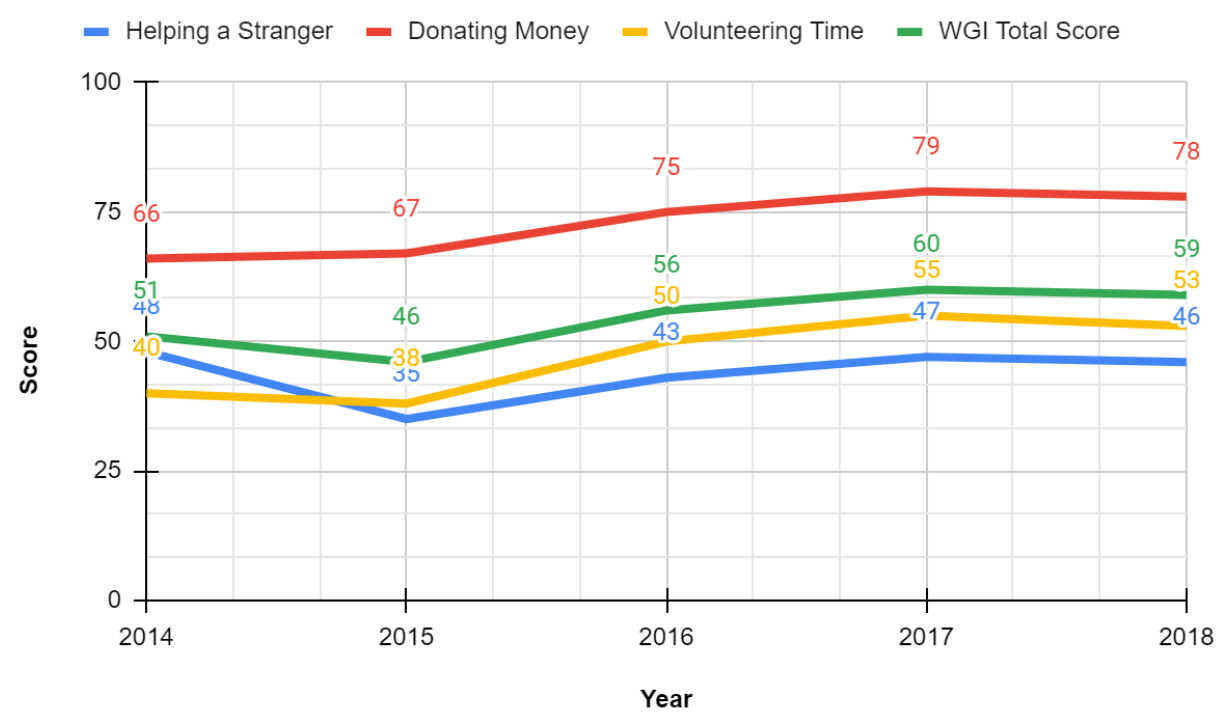

Graphic 1. Indonesia WGI Score by Indicator (2014 - 2018) Source: CAF (2014-2018), Compiled by Author 
If depicted in a ranking based graph, Indonesia WGI rank for the period 2014 - 2018 is as follows:



Graphic 2. Indonesia WGI Rank (2014 - 2018)

Source: CAF (2014-2018), Compiled by Author

Based on this graph, Indonesia has experienced a significant ranking increase from year to year. In 2014, Indonesia was ranked 13th, then dropped to 22nd in 2015, then in 2016 to 2018, Indonesia's ranking increased until finally being ranked first. Although in 2018, Indonesia ranked first in the WGI, on the other hand, Indonesia's Gross Domestic Product (GDP) is arguably not the most superior compared to other countries. This fact can be seen from the World Bank in the same year placing Indonesia in the sixteenth position in GDP based on the current US dollar price and the eighth position based on GDP with the current price PPP assessment. Of course, there are various factors behind this. Data shows that income is not the main factor that encourages someone to give alms.

Table 1. GDP 2018 Comparison Between G20 Countries

\begin{tabular}{|l|c|c|c|c|}
\hline \multicolumn{1}{|c|}{ Countries } & $\begin{array}{c}\text { GDP PPP Current } \\
\text { USD }\end{array}$ & Rank & GDP Current USD & Rank \\
\hline China & 21414903677240 & 1 & 13608151864638 & 2 \\
\hline USA & 20544343456936 & 2 & 20544343456937 & 1 \\
\hline India & 9058691685480 & 3 & 2718732231258 & 7 \\
\hline Japan & 5247580835384 & 4 & 4971323079772 & 3 \\
\hline Germany & 4514794305293 & 5 & 3947620162503 & 4 \\
\hline Russia & 4192936665935 & 6 & 1657554647150 & 11 \\
\hline Brazil & 3131944308264 & 7 & 1885482534238 & 9 \\
\hline Indonesia & 3117334244159 & 8 & 1042173300626 & 16 \\
\hline
\end{tabular}




\begin{tabular}{|l|c|c|c|c|}
\hline United Kingdom & 3114857833941 & 9 & 414178942592 & 28 \\
\hline France & 3110915153134 & 10 & 2855296731522 & 5 \\
\hline Italy & 2585936449485 & 11 & 2777535239278 & 6 \\
\hline Mexico & 2573847595048 & 12 & 2083864259623 & 8 \\
\hline Turkey & 2316406545201 & 13 & 1220699479846 & 15 \\
\hline South Korea & 2046766341230 & 14 & 771350330455 & 19 \\
\hline Spain & 1894494241788 & 15 & 1619423701170 & 12 \\
\hline Canada & 1852669162036 & 16 & 1419041949910 & 14 \\
\hline Saudi Arabia & 1643080030917 & 17 & 1713341704877 & 10 \\
\hline Thailand & 1283169739289 & 18 & 786521831572 & 18 \\
\hline Australia & 1275026604984 & 19 & 504992757705 & 25 \\
\hline Poland & 1205917498455 & 20 & 1433904348500 & 13 \\
\hline
\end{tabular}

Source: World Bank (2018)

Regarding the relationship between almsgiving and income, Islam views that having wealth or ownership is only a means. In the Qur'an, Allah mentions the word al-maal (wealth) in its various forms 86 times in 79 verses in 38 Surahs. The word al-maal in all its forms was mentioned 86 times. Twentyfive times in the singular (مال (maal)) and 61 times in the plural (أموال (amwaal)). In the Qur'an, Allah always calls the word amwal (إلضانة) (idafah)) with a plural pronoun. Of the six times the word maal is paired with a singular pronoun, 5 of them have the connotative tone of being wrong, despicable, and despicable. The verses implies that the wealth must be channeled and appropriately managed correctly. Besides that, in Islam, having wealth is not a necessary condition for doing philanthropic action. Islam also emphasizes that making philanthropic action effort is necessary for having more wealth.

Various studies have also tried to test the relationship between alms and income. It is still uncertain whether income and level of alms correlate with each other. Jones and Posnett (1991) revealed that an increase in the behavior of giving charity is not in line with an increase in household income. On the other hand, there is a significant positive relationship between income and one's level of alms (Mohd Arshad, 2016). The two types of research mentioned (Jones and Posnett, 1991; Mohd Arshad, 2016) conducted testing at the micro-level. Therefore, this study aims to determine the correlation between income and the level of alms, which is more concentrated at the macro level, namely by using GDP and WGI. This study will also examine this correlation more deeply by using an Islamic perspective to determine Muslim behavior in charity. The large population of Indonesia who is Muslim, namely 87.2\% in 2010.

\section{Literature Review}

\section{Gross Domestic Product (GDP)}

One measure to calculate the value of a country's economic activity is to 
use the Gross Domestic Product (GDP). GDP is the market value of the final goods and services produced in a country in a specific period (Parkin, 2012). GDP is often considered the best measure of how well an economy is performing. There are two ways to look at GDP calculations (Mankiw, 2014). One way of looking at GDP is as the total income of everyone in the economy and the total expenditure on the economy's output of goods and services. From these two points of view, it is clear why GDP is a measure of economic performance. Although GDP is not a perfect measure of wellbeing, it reflects shows people care about their income allocation.

\section{Charity}

Charitable giving is a manifestation of altruistic behavior (Mohd Arshad, 2016). To understand the habit of giving, economists usually use a concept introduced by Hochman and Rodgers (1970). They propose a utilitarian framework of pareto-optimal redistribution based on the assumption of utility interdependence - one's utility is another's a utility function. Therefore, charity increases not only the utility of the recipient but also the utility of the giver.

There are internal factors and external factors that encourage someone to have the habit of giving (Kasri, 2013). The first is external factors including demographic and socioeconomic variables such as age and gender (Halfpenny, 1990) and income levels and education levels (Jones and Posnett, 1991). Meanwhile, an individual's internal factors are related to their religion, as part of their support and concern for their faith (Jackson, 2001; Kochuyt, 2009).

\section{Islamic Perspectives on Charity (Almsgiving)}

The spirit to do good deeds by the teachings of Islam, which is the encouragement to give alms (Kasri, 2013). This teaching is exactly what found in QS. Adz-Dzariyat verse 19, "and on their property (there is) the right of the poor who ask and the poor who do not ask." found in QS. Al-Baqarah verse 261, "The parable (alimony issued by) those who spend their wealth in the way of Allah is like a seed that grows seven grains, in each grain a hundred seeds. Allah doubles (reward)for whom He wills. And Allah is All-Wise, All-Knowing." A study conducted by Pharoah and Tanner (1997) adds that people consider religion important in giving more charity.

Almsgiving is an act of worship that has transcendental and horizontal dimensions (Nofiaturrahmah, 2016). Almsgiving gives a lot of meaning in lives of Muslims as well Muslims lives and the saves of Muslims and humankind as a whole. Almsgiving has many pearls of wisdom, such as the manifestation of faith, one form of gratitude, helping to improve others' standard of living to be more prosperous. Almsgiving can create a balance in the distribution of 
property, a balance in property ownership, and a balance of individual responsibilities in society.

Obaidullah (2008) (in Yumna and Clarke (2009)) notes that alms can include various forms of charity, such as tabarruat (donations), hibah (gifts), infaq (expenditure of charity) and can be in the form of good deeds, such as smiling and helping people is in trouble.

\section{Previous Research}

As far as the author observes, no studies have examined the relationship between charitable and macro income. Mostly, research on this is done micro or at the individual data level.

\section{What is the Real Relationship between Income and Charitable Giving?}

In a study conducted by McClelland and Brooks (2004), income, education, number of families, age, and status influence a person's contribution. In this study, income divided into current income and permanent income. The results found that both current income and permanent income significantly influence a person's contribution.

\section{Determinants of Charitable Giving in Malaysia}

Research conducted by Mohd Arshad (2016) found that, in general, factors such as income, age, education level, marital status, gender, and geographic location have a statistically significant influence on Malaysian charity giving. A 1 percent increase in income would result in a 1.5 percent increase in charitygiving, ceteris paribus. In Malaysia, charity giving increases and peaks initially at 40 before declining slowly over the working period (inverted U curve shape). Women account for 8.7 percent more than men. High school has the highest marginal effect on charity giving at 10.7 percent. After high school, the marginal impact of subsequent levels of education on charitable giving diminishes.

\section{Giving Behaviors in Indonesia: Motives and Marketing Implications for Islamic Charities}

Kasri (2013) conducted research to examine the motives and behavior of donating to alms in Indonesia using demographic, socioeconomic, psychographic, and motivational/situational characteristics. Researchers managed to collect primary data as many as 300 Indonesian Muslims who gave alms. The results showed that the primary motive for giving alms was to help the poor and to support religious goals. Then, most of the charity channeled through informal Islamic charities, and the respondents are youth, educated, and have strong humanitarian concerns. Interestingly, although there is a positive correlation between income and alms, more individuals give alms than those with middle income have more individuals. 
The Relation Between Income and Donations as a Proportion of Income Revisited: Literature Review and Empirical Application

Neumayr \& Pennerstorfer (2020) conducted this study due to the increasing income inequality between low and high-income groups in most western countries. However, this study focuses on examining the behavior of people in Austria. This study's results indicate several conclusions, among which, such as people from low-income groups tend to donate more of their income. On the other hand, the relationship between income and the level of donations made to high-income groups is more difficult to explain. These donations include contributions to charitable organizations that provide public benefits, emergency assistance, development assistance, or animal and environmental protection that have registered with the Ministry of Finance, except for churches.

\section{Research Methods}

\section{Research Approach}

This study uses a quantitative correlational approach, where the researcher wants to know the relationship between a country's national income variable and the index of charity (WGI).

\section{Data Sources}

This study uses 2018 GDP data provided by the World Bank and 2018 WGI data prepared by the CAF. The GDP data used is based on an assessment of purchasing power parity or Purchasing Power Parity (PPP). With the PPP assessment, the calculated GDP has issued an inflation factor reflect GDP in real terms. Meanwhile, the World Giving Index (WGI) is a report that describes the charitable behavior and nature of giving from 146 countries around the world. The WGI created by CAF, the UK's leading international charity. It has been a decade since WGI was created, namely in 2009, and the most recent released in October 2019. During that decade, CAF analyzed giving behavior worldwide by surveying more than1.3 a million people through the Gallup World View World Poll. There are three aspects to measuring this index helping foreigners, donating money, and participating in voluntary activities. In most of the countries surveyed, the 1000 questionnaire was completed by a representative sample of individuals living in all countries, including rural areas. Sampling was represented by all civilians aged 15 years and over from all countries. In some countries with a larger population, the sample will be more significant. The survey is conducted by telephone or face-to-face, depending on the telephone coverage of the country. In this survey, Gallup uses a confidence interval of $95 \%$, and the number of random sampling errors (margin of error) is 5\%, assuming a reported percentage of $50 \%$. 


\section{Variable Construction}

This research uses the conceptualization and operationalization of the following variables.

Table 2. Conceptualization and Operationalization of Variables

\begin{tabular}{|c|l|}
\hline Variable & \multicolumn{1}{c|}{ Definition } \\
\hline GDP & $\begin{array}{l}\text { The market value of the final goods and services produced in } \\
\text { a country in a certain period. GDP used comes from the } \\
\text { World Bank and uses the purchasing power parity } \\
\text { assessment. }\end{array}$ \\
\hline $\begin{array}{c}\text { Charity Behavior } \\
\text { Index }\end{array}$ & $\begin{array}{l}\text { An index that measures a country's charitable behavior with } \\
\text { data from the CAF. }\end{array}$ \\
\hline
\end{tabular}

Source: Compiled by Author

\section{Analysis Method}

In this study, data analysis used descriptive and inferential methods. Statistical descriptive analysis to explain a more comprehensive overview and understanding of the current information between the variables used. Meanwhile, inferential analysis used to understand whether the national income variable that correlates with the index of charity behavior. In inferential analysis, the Spearman Rank Test will be used.

Spearman's rank correlation, a nonparametric version of the Pearson correlation coefficient, was used to measure the relationship between two variables (Jaggia and Kelly, 2016). Spearman's rank correlation measures the correlation between two random variables based on rank order. The values range between -1.00 and +1.00 and are interpreted in the same way as the Pearson correlation coefficient. A value of -1.00 indicates a perfect negative relationship between ratings, and a value of 1.00 means an ideal relationship between ratings. A value of 0 indicates that there is no relationship between the ratings. This method makes no assumptions about the $\mathrm{d}$ at a distribution and is an appropriate correlation analysis when variables measured on an ordinal scale. The following is the formula for measuring the Spearman rank correlation test:

$$
r x y=1-\frac{6 d^{2}}{N\left(N^{2}-1\right)}
$$

Explanation: 
coefficient $\mathrm{d}$ : Difference in ranking between $\mathrm{x}$ and $\mathrm{y}$

$\mathrm{N}$

: The number of observation subjects

\section{Research Hypothesis}

There is no relation between national income and charitable behavior index.

\section{Result and Discussions}

\section{Analysis of the Relation between WGI and GDP}

We can illustrate the relation between WGI and GDP can be at a glance through the scatter plot in the graphic below. This graph shows the distribution of data centered on lower GDP, and the correlation between WGI and GDP is not yet clear. However, if a trend line drawn, it indicates a positive relationship.

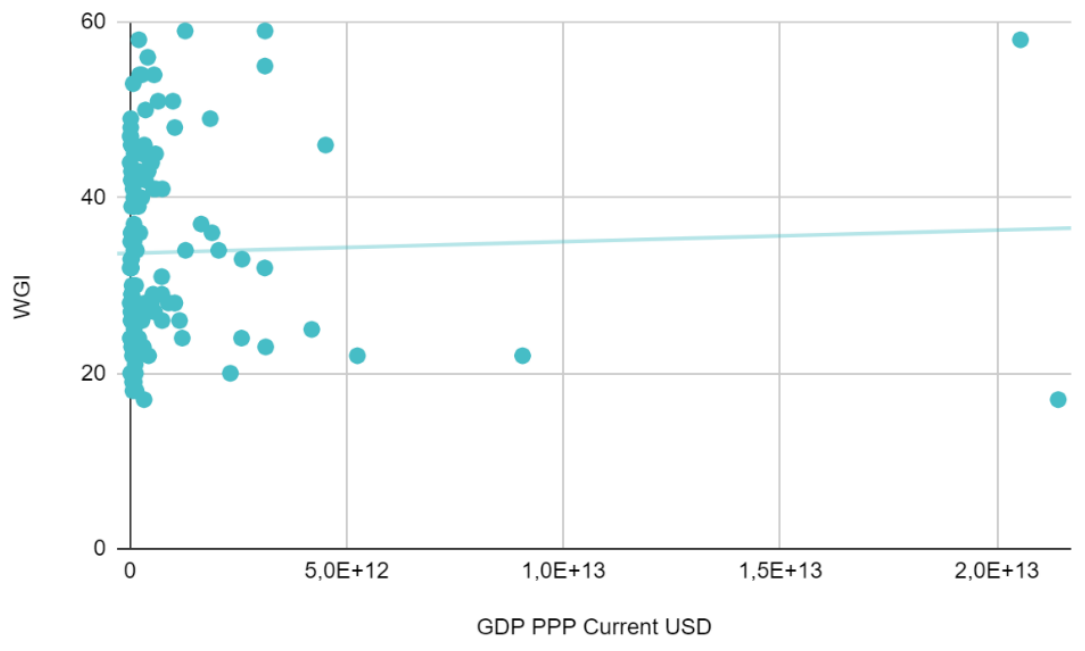

Graphic 3. Scatter Plot WGI and GDP (PPP Current USD) Source: Compiled by Author

To test the correlation between WGI and GDP, the authors use the Spearman rank correlation whose results are shown as follows:

Table 3. Spearman Rank Test Result

\begin{tabular}{|l|l|}
\hline Number of obs $=$ & 140 \\
\hline Spearman's rho $=$ & 0.0785 \\
\hline Test of Ho: GDP PPP Current and WGI are independent \\
\hline Prob $>\mathrm{t}=$ & 0.3568 \\
\hline
\end{tabular}


The number of observations consists of 140 countries. The results obtained are that the relationship between WGI and GDP is not significant at the 0.05 significance level. Data indicated by the p-value greater than 0.05 or 0.3568 . Although the Spearman correlation coefficient between WGI and GDP is 0.0785 , indicating a positive relationship, the two variables are independent or do not significantly correlate.

The results above indicate that the level of a country's national income does not correlate does not correlate with the level of alms of the country's population. Previous research has shown inconsistent findings regarding the effect of income on the probability of giving and the proportion of income spent on charity. For example, study at the individual level by Wiepking (2007) also found no effect of income on the likelihood of someone giving or giving charity.

Table 4 below shows the WGI comparison by category per capita income. The classification based on GNI per capita (Current USD) of each country and four group classifications based on the latest World Bank guidelines. It is undeniable that the ten countries in the high-income category have a charitable behavior index or a high WGI score of more than 50. This result $i$ is following the research conducted by Jasper and Samek (2014) that charity's behavior (charitable giving) is continuously increasing in the country. Up. For example, USA philanthropy contributes more than 2 percent of US GDP to philanthropic organizations in 2013. According to the World Giving Index, about 50-60 percent of households in developed countries donate or give charity.

Meanwhile, only 3 countries from the lower-middle income group, namely Indonesia, Kenya, and Myanmar, have a high WGI of more than 50. The table also shows 38 countries from the lower-middle-income group have quite high WGI, namely between 30-49, considering that the average WGI score of the whole country was 33.79 .

Table 4. Comparison of WGI based on 2018 Per Capita Income Category

\begin{tabular}{|c|c|c|c|c|c|}
\hline Per & \multicolumn{5}{|c|}{ WGI Score } \\
\hline $\begin{array}{l}\text { Income } \\
\text { Category }\end{array}$ & $\geq 50$ & $40-49$ & $30-39$ & $20-29$ & $<20$ \\
\hline $\begin{array}{l}\text { Lower } \\
\text { Income }\end{array}$ & & $\begin{array}{l}\text { Haiti, Liberia, } \\
\text { Sierra Leone, } \\
\text { Gambia, } \\
\text { Tajikistan, }\end{array}$ & $\begin{array}{l}\text { Uganda, } \\
\text { Nepal, Congo } \\
\text { Dem. Rep, } \\
\text { Malawi, } \\
\text { Central } \\
\text { African } \\
\text { Republic, }\end{array}$ & $\begin{array}{l}\text { Burkina Faso, } \\
\text { Mozambique, Mali, } \\
\text { Tanzania, Chad, } \\
\text { Ethiopia, } \\
\text { Madagascar, } \\
\text { Rwanda, Togo }\end{array}$ & $\begin{array}{l}\text { Afghanista } \\
\mathrm{n}\end{array}$ \\
\hline
\end{tabular}




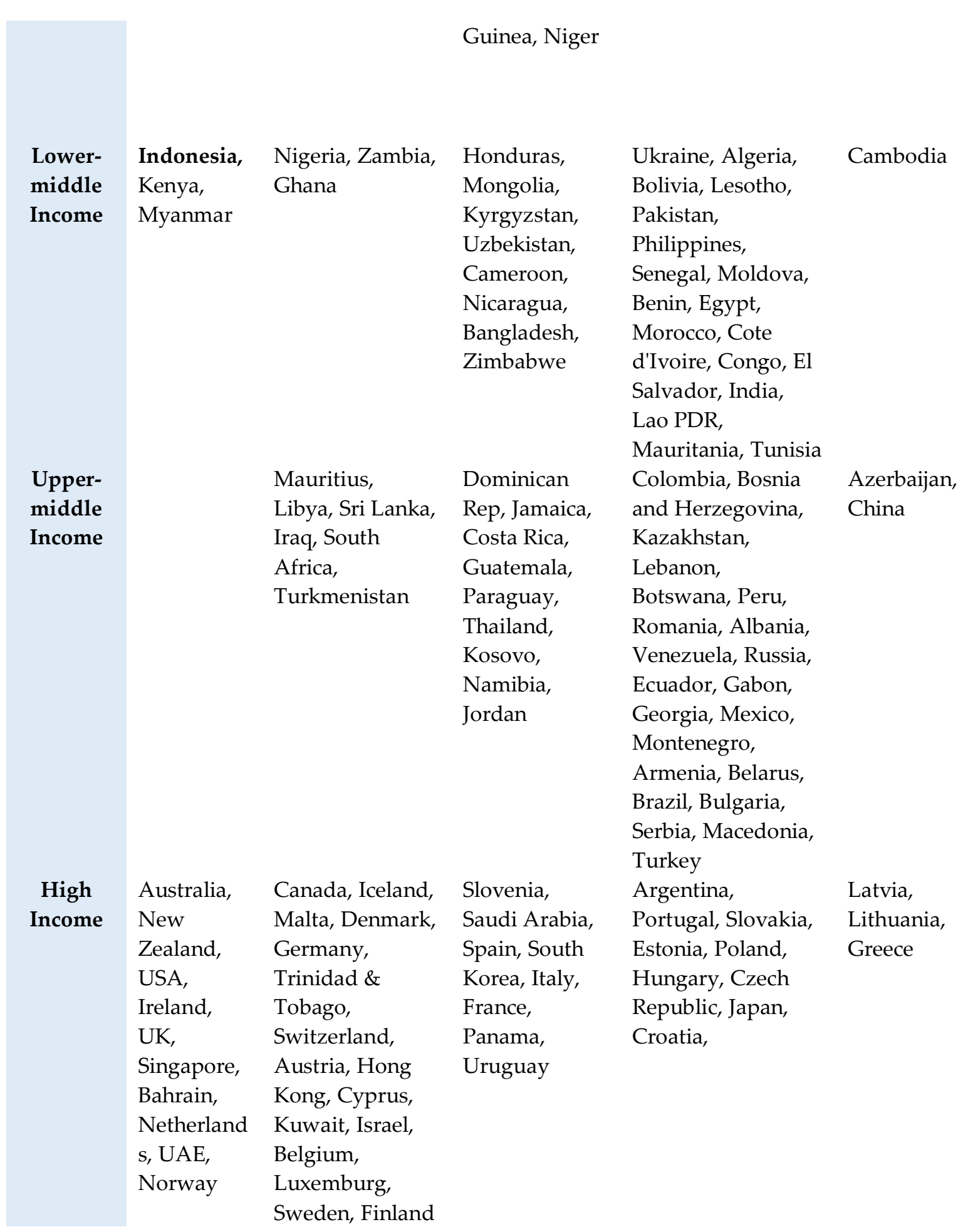

Source: World Bank (2018); Charities Aid Foundation (2018), Compiled by Author

\section{Comparison between Other Countries}

Compared to ASEAN countries with the same vision, mission, and interests in terms of economy, politics and security, and socio-culture (setnas-asean.id, 2017), Indonesia is still the most superior in the WGI ranking. ASEAN countries included in the WGI ranking in 2018 are Indonesia, Cambodia, Laos, Myanmar, the Philippines, Singapore, and 
Thailand. On the other hand, Malaysia, Brunei Darussalam, and Vietnam are not included in the WGI ranking. In this regard, it is not specifically explained why the country is not included in the WGI ranking. These ASEAN countries have varying rankings in world rankings. Indonesia occupies the top three ASEAN rankings occupies the top three ASEAN rankings occupies the top three ASEAN rankings occupies the top three ASEAN rankings as first place (World Rank 1), Singapore as second (World Rank 7), then followed by Myanmar as the third rank (World Rank 9).

Indonesia and Myanmar in particular, are among the most religious countries in the world. As a survey conducted by the Gallup International Association (GIA) in 2009, 99\% of Indonesians and 97\% of Myanmar people surveyed considered religion important (GIA, 2009). Indonesia itself, the majority of the population is Muslim, while Myanmar is predominantly Buddhist. This shows that people who consider religion to be important in their lives tend to give more charity, as explained in the research of (Pharoah and Tanner, 1997).

On the other hand, the three lowest rankings of ASEAN are occupied by the Philippines as 89th place, Laos at 134th, and finally Cambodia at 140th in the world. This can be seen in the graph below:

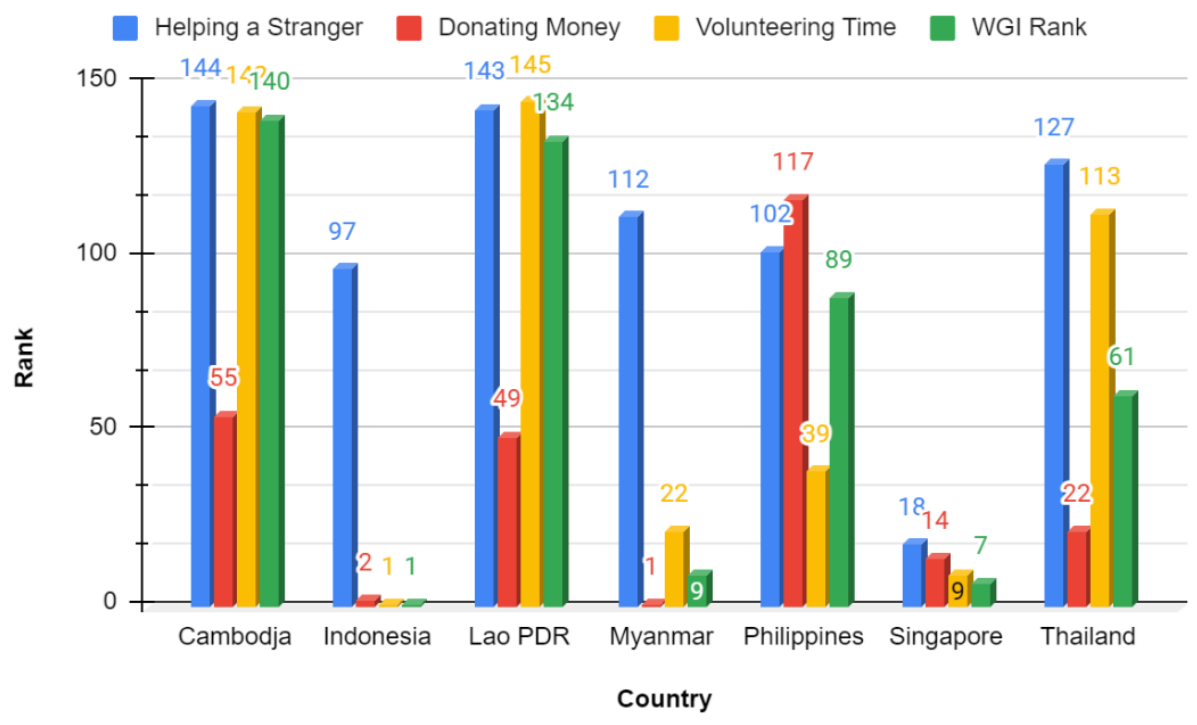

Graphic 4. ASEAN WGI Rank 2018

Source: Charities Aid Foundation (2018), Compiled by Author

Even though they have varying rankings in world rankings, ASEAN countries in general still have similarities. Among them are like being superior in donating money, on the other hand being left behind in participating in voluntary activities. This fact can be seen in the graph below: 




Graphic 5. ASEAN WGI Score 2018

Source: Charities Aid Foundation (2018), Compiled by Author

When compared with other Muslim countries that are members of the Organization for Islamic Cooperation, the top 10 countries with the best scores and rankings in the world are as follows:

Table 5. Top 10 WGI of OIC Countries

\begin{tabular}{|l|c|c|c|c|c|}
\hline \multicolumn{1}{|c|}{ Country } & Classification & $\begin{array}{c}\text { GDP } \\
\text { Rank }\end{array}$ & $\begin{array}{c}\text { WGI } \\
\text { Score }\end{array}$ & $\begin{array}{c}\text { WGI } \\
\text { Rank }\end{array}$ & $\begin{array}{c}\text { OIC } \\
\text { Rank }\end{array}$ \\
\hline Indonesia & LM & 8 & 59 & 1 & 1 \\
\hline Bahrain & H & 90 & 53 & 10 & 2 \\
\hline Nigeria & LM & 23 & 48 & 16 & 3 \\
\hline Sierra Leone & L & 135 & 47 & 20 & 4 \\
\hline Libya & UM & 79 & 45 & 28 & 5 \\
\hline Gambia & L & 139 & 44 & 30 & 6 \\
\hline Kuwait & H & 59 & 43 & 32 & 7 \\
\hline Iraq & UM & 43 & 43 & 33 & 8 \\
\hline Tajikistan & L & 120 & 42 & 35 & 9 \\
\hline Turkmenistan & UM & 85 & 40 & 42 & 10 \\
\hline
\end{tabular}

*L means Lower Income Country; LM means Lower-middle Income Country; UM means Upper-middle Income Country, and H means High Income Country.

Source: Compiled by Author

It can be seen in table 4 . above that country with a majority of the 
Muslim population and joining the OIC have a reasonably high score in terms of WGI, namely in the 40-59 range, which is far from the average WGI score of the whole country of 33.79. This condition is in line with the advice in Islam to increase alms. Uniquely, in the table above, it can be seen that these countries are not the countries with the highest GDP ranking in the world. Tajikistan, Sierra Leone, and the Gambia are among the 20 lowest rankings of GDP and are included in the lower-income classification. Indonesia, as the first ranked WGI in the world, is an Islamic country in the lower-middle-income category. This fact shows that there is no need to wait for the rich to give alms.

\section{Research Implication}

The test results with the Spearman rank correlation show no correlation between WGI and GDP. This research is still minimal, and it is necessary to conduct further and comprehensive research on the relationship and influence of a country's national income on the level of alms in that country. Based on this research, we can see that there is great potential in giving alms by the Indonesian people, apart from Indonesia being a lowermiddle-income country.

For example, during the current pandemic, Indonesian society has seen an increase in philanthropic institutions. Quoting the words of the President Director of BAZNAS, M. Arifin Purwakananta, public donations during Covid-19 at BAZNAS have increased (Republika.co.id, 2020a). We know that the economic crisis impact on Covid-19 has caused the number of muzakki (zakat givers) to decrease because the income of people who reach zakat nishab has also decreased, both employers and employees. Therefore, zakat earning expected to decrease (Republika.co.id, 2020b). However, the concern and enthusiasm of people donating are not limited to the giving of zakat, which has now turned into donations in the form of alms and offerings. LinkAja's head of corporate communication Putri Dianita also said that the donation trend had also increased significantly from LinkAja's strategic partners such as Kitabisa, Rumah Zakat Dompet Dhuafa (Evandio, 2020).

Based on the potential and reality that occurs in philanthropic institutions today, we recommend several things, including the following:

a. This research can serve as a reference for philanthropic institutions in optimizing their role in the collection, management, and distribution of alms.

b. The importance of branding carried out by philanthropic institutions, especially the ZISWAF institution, is that they accept zakat but also other forms of donations such as alms and infaq. 
c. The government as a policy maker can provide the support that makes it easier for philanthropic institutions to grant permits and the monitoring process.

d. The government can help the digitization process, such as carrying out infrastructure development in various parts of the country.

\section{Conclusion}

The Spearman rank correlation results show that there is no relationship or correlation between the WGI and GDP of a country. Although the Spearman correlation coefficient between WGI and GDP is 0.0836, indicating, indicating a positive relationship. The two variables are separated or do not significantly correlate. This fact shows that the level of national income of a country does not correlate does not correlate with the level of alms of the population in that country. Compared to other countries globally, Indonesia is the most generous country, as reflected in the WGI. On the other hand, Indonesia is in the classification of a lowermiddle-income country.

This research is still minimal. It is necessary to conduct a further and comprehensive study on the relationship and influence of a country's national income on the level of alms in that country. Given the enormous potential and realities of the donation group in Indonesia, philanthropic institutions and the government can optimize the collection, management, and distribution processes and support the digitization process.

\section{References}

[1]Charities Aid Foundation. (2018). CAF World Giving Index 2018 (Issue October).

[2] Evandio, A. (2020). Donasi Digital Meningkat Selama Pandemi Covid-19. Finansial.Bisnis.Com. https://finansial.bisnis.com/read/20200519/563/1242695/donasidigital-meningkat-selama-pandemi-covid-19

[3]GIA. (2009). Importance Religion by Country. News.Gallup.Com. https://news.gallup.com/poll/1690/religion.aspx

[4]Halfpenny, P. (1990). Charity Household Survey 1988/89: Findings from a National Survey. Charities Aid Foundation.

[5]Hochman, H. M., \& Rodgers, J. D. (1970). Pareto Optimal Redistribution: Reply. American Economic Review.

[6]Jackson, T. D. (2001). Young African Americans: a new generation of giving behaviour. International Journal of Nonprofit and Voluntary Sector Marketing. https://doi.org/10.1002/nvsm.150

[7]Jaggia, S., \& Kelly, A. (2016). Business Statistics: Communicating with Numbers. In The Mathematical Gazette.

[8]Jasper, C. R., \& Samek, A. S. (2014). Increasing charitable giving in the developed world. Oxford Review of Economic Policy. https://doi.org/10.1093/oxrep/gru032

[9] Jones, A., \& Posnett, J. (1991). Charitable donations by UK households: Evidence from the Family Expenditure Survey. Applied Economics. 
https://doi.org/10.1080/00036849100000143

[10]Kasri, R. A. (2013). Giving behaviors in Indonesia: Motives and marketing implications for Islamic charities. Journal of Islamic Marketing. https://doi.org/10.1 108/JIMA-05-201 1-0044

[11]Kochuyt, T. (2009). God, gifts and poor people: On charity in Islam. Social Compass. https://doi.org/10.1177/0037768608100345

[12]Mankiw, N. G. (2014). Principle of economics. In Igarss 2014.

[13] McClelland, R., \& Brooks, A. C. (2004). What is the real relationship between income and charitable giving? In Public Finance Review. https://doi.org/10.1 177/1091142104266973

[14]Mohd Arshad, M. N. (2016). Determinants of charitable giving in Malaysia. Humanomics. https://doi.org/10.1108/H-01-2016-0007

[15]Neumayr, M., \& Pennerstorfer, A. (2020). The Relation Between Income and Donations as a Proportion of Income Revisited: Literature Review and Empirical Application. Nonprofit and Voluntary Sector Quarterly. https://doi.org/10.1 177/0899764020977667

[16] Nofiaturrahmah, F. (2016). Pengumpulan dan pendayagunaan zakat infak dan sedekah. Jurnal Zakat Dan Wakaf, 2 (2), 279-295.

[17]Parkin, M. (2012). Economics (10th ed.). Pearson.

[18]Pharoah, C., \& Tanner, S. (1997). Trends In Charitable Giving. 18(4), 427-443. https://doi.org/https://doi.org/10.1111/j.1475-5890.1997.tb00272.x

[19]republika.co.id. (2020a). Anomali Kedermawanan Kala Pandemi COVID 19. Republika.Co.Id. https://www.republika.id/posts/6781/anomali-kedermawanan-kalapandemi- covid-19

[20]republika.co.id. (2020b). Baznas: Donasi Masyarakat Selama Pandemi Naik. Republika.Co.ld. https://republika.co.id/berita/q9i31w483/baznas-donasi-masyarakatselama- pandemi-naik

[21]setnas-asean.id. (2017). ASEAN Selayang Pandang. Setnas-Asean.ld. http://setnasasean.id/site/uploads/document/book/5a3c8377e89ce-asean- selayang-pandangv15-lowres.pdf

[22]Wiepking, P. (2007). The philanthropic poor: In search of explanations for the relative generosity of lower income households. Voluntas. https://doi.org/10.1007/s11266-0079049-1

[23]World Bank. (2018). World Bank Open Data. Data.Worldbank.Org. https://data.worldbank.org/indicator/NY.GDP.MKTP.PP.CD

[24]Yumna, A., \& Clarke, M. (2009). Integrating zakat and Islamic charities with microfinance initiative in the purpose of poverty alleviation in Indonesia. 8th International Conference on Islamic Economics and Finance. 